\title{
STUDY OF DIFFERENT TYPES OF GRAFT MATERIALS USE IN TYPE - I TYMPANOPLASTY AT ENT DEPARTMENT OF SKMCH, MUZAFFARPUR, BIHAR
}

\section{ENT}

\section{Dr. Mukul Kumar Sinha*}

M.B.B.S., M.S. (ENT), Associate Professor, Department of ENT and Head \& Neck Surgery, Sri Krishna Medical College \& Hospital, Muzaffarpur, Bihar. *Corresponding Author

Young Scientist (DST), Institute of Post-Graduate Medical Education and Research, A.J.C. Bose Road, Kolkata, West Bengal, India-700020.

\section{Dr. Debarshi Jana}

\section{ABSTRACT}

Background:The present study was undertaken to compare the results of various autogenous tissues as grafting materials for the repair of the tympanic membrane defect. As all the materials used previously were not easily available. So the present study comprised of the materials, which were easily available in adequate amount. These were temporalis fascia, tragalperichnodrium, areolar tissue and Ear lobule fat

Methods: In 100 subjects tympanoplasty operation was performed in 100 ears. The age of subjects ranged from 11 years to 50 years with mean age being 28.9 years. 33 cases were male and 67 cases were female. Majority (62\%) of them were residing in rural areas and rest ( $38 \%)$ were from urban population. The period of study was from May 2019 to April 2020 starting from the pre-operative assessment to post- operative follow up all findings were noted in specific proforma. All of them attended ENT outpatient department of Sri Krishna Medical College and Hospital, Muzaffarpur, Bihar, with the chief complaints of discharging ear of varying duration. Slight impairment of hearing of varying degree was also complained of. Few of them presented with active stage of the disease and they were treated conservatively so that they attained the criteria as mentioned previously for myringoplasty operation of the present study.

Results: Temporal fascia - None of the operated case reached the excellent result of post operative A-B gap closure by $0-10 \mathrm{~dB} .23$ cases showed good A-B gap closure of $11-20 \mathrm{~dB}$ followed by 9 cases with fair A-B gap closure of $21-30 \mathrm{~dB}$ and 5 cases showed poor result of $>30 \mathrm{~dB}$ A-B gap closure. Tragal perichondrium -None of the operated case reached the excellent result of post operative A-B gap closure by $0-19 \mathrm{~dB} 5 \mathrm{cases}$ showed good A-B gap closure by $11-20 \mathrm{~dB}$, followed by 3 cases of fair A-Bgap closure $21-30 \mathrm{~dB}$ and 1 case of poor result with $>30 \mathrm{~dB} A-\mathrm{B}$ gap closure.Areolar tissue - None of the operated case reached the excellent result of post operative A-B gap closure by $0-10 \mathrm{~dB}$. 6 cases showed good A-B gap closure by $11-20 \mathrm{~dB}$, followed by 2 cases of fair i.e. $21-30 \mathrm{~dB}$ A- B gap closure. Ear Lobule fat -8 out of 45 cases showed excellent result with post operative A-B gap closure by $0-10 \mathrm{~dB}$ followed by 32 cases with good A-B gap closure by $11-20 \mathrm{~dB}$, followed by 5 cases of fair i.e. $21-30 \mathrm{~dB}$ A-B gap closure.

Conclusion:Tympanoplasty using Fat from ear lobule has high success rate of $90 \%$ for tiny small perforations. It is an office procedure which is cost effective with minimum post operative morbidity. But it is an underused procedure. We should practice it more for the benefit of our patients. Further long term study with more number of patients and verities of graft materials are necessary to achieve detailed and accurate results.

\section{KEYWORDS}

Temporal fascia, Tragal perichondrium, Areolar tissue, Ear Lobule fat.

\section{INTRODUCTION}

Type I tympanoplasty is used to repair the tympanic membrane when there is an eardrum perforation and the ossicular chain is undamaged and mobile.Tympanic membrane (TM) closure is one of the most common surgical procedures in otologic practice. The repair of tympanicmembrane (TM) dates back more than a century. In 1878 Berthold successfully closed a perforation with full thickness skin graft.Since then, repair of the tympanic membrane has been attempted with large variety of synthetic, homologous, and autogenous tissue; however, temporalis fascia areolar tissue and perichondrium are used most commonly today. No surgeon (however experienced) escapes complication. Many changes in technique and in the choice of the graft material have been tried even today. As such there is no universally accepted opinion as regards technique and materials used were best for the repair of the tympanic membrane.

As suggested by many authors ${ }^{2}$ that Type -1 Tympanoplasty is simple and safe procedure in a chronic suppurative otitis media with dry central perforation in an otherwise normal ear with intact ossicular chain. Type I - Tympanoplasty operation could prevent recurrent infection from external canal source by making the ear waterproof. It also would convert the open middle ear into a cul-de-sac, so that free flow of air could prevent the infected mucus up the Eustachian tube from the nasopharynx. Packer et $\mathrm{al}^{3}$ (1982) showed that with intact ossicular chain, hearing was significantly improved by closure of the perforation.

This present study was undertaken to compare the easily available autogenous graft material i.e. temporalis fascia, tragal perichondrium areolar tissue and ear lobule fat with regard to their suitability for use as tympanic membrane grafts. The study also compared the result of these grafts in various aspect though of prime interest was the permanent closure of tympanic membrane perforation and hearing restoration of the successfully grafted ear.

AIMS AND OBJECTIVES

1) To study the success of the graft intake in four antogenous graft

\section{materials.}

2) To evaluate Healing and Hearing of these four grafted materials used in Tympanoplasty operation with regards to-

- The age of the subjects.

- The site of the perforation

- The size of the perforation

- Mastoid pneumatization.

And to find out the best tissue material which could give rise to better results both in repair of the perforated tympanic membrane and hearing improvement within our available facilities and conditions.

Correlate my results with already available grafting results.Obtain a statically data for the same as studied in local population.

\section{MATERIALAND METHODS}

The present study was carried out in the ENT Department of Sri Krishna Medical College and Hospital,Muzaffarpur, Bihar. 100 subjects were selected from the outpatient department of ENT, 33 subjects were male and 67 were female ranging from 13 to 48 years. All the subjects were judged clinically and with investigations i.e. routine haemogram, X-ray of mastoid (Law's lateral oblique view), X-ray of paranasalsinuse (Occipito-mental view) and special test where required. Pure tone audiometry was performed in both air conduction and bone conduction in all subjects. Selection criteria's of the individual for this present study were;

1. Adult subjects were preferred.

2.Chronic suppurative otitis media with central perforation though location and size of the perforation were variable.

3. Dry ear for at least three months.

4. Other ear was normal.

5.Pure-conductive type of deafness was confirmed by pure-tone audiometry.

6.Except the ear disease there was no other disease condition, which could affect the results of the study.

Before operation every ear was inspected under operative microscope. 
In this study group tympanoplasty operations were performed using various autogenous tissues as grafting materials i.e. temporalis fascia were used in 36 ears, tragalperichodrium used in 9 ears, areolar tissue in 9 ears, and Ear Lobule fat in 46 ears. All the selected 100 ears were operated under operative microscope model Zeiss OPMI-1 using the magnification of 0.4 to 0.6 with $12.5 \mathrm{x}$ eye piece and $200 \mathrm{~mm}$ lens. 100 ears were operated under local anaesthetic infiltration with $2 \%$ lignocaine in adrenaline $(1: 1,00,000)$. Inj. Pethidine $(75 \mathrm{mg})$ intramuscularly. In. phenargan $(25 \mathrm{mg})$ intramuscularly. The premeditation was administered $1 / 2$ an hour before the patient was taken to operation theatre.

10 ears were operated under general anaesthesia with endotracheal intubation with hypotensive technique. After shaving and antiseptic dressing of the planned temporal area. Subjects were taken to operation theatre. The subject was placed supine on the operating table with the head supported on a rubber ring and rotated to the opposite side. The entire table was tilted head up slightly (about $30^{\circ}$ ). The neck was in extended position. Antiseptic dressing with Betadine solution and rectified spirit then the operated area was covered with sterile drapes. Then local anaesthetic infiltration of the ear was done in 90 cases. Local infiltration in the selected sites (temporal area - for temporalis fascia and areolar tissue, tragal region- for tragal perichondrium, and ear lobule for fat was also done.

\section{RESULTS}

100 Patients suffering from unilateral chronic suppurative otitis media had undergone Type -I tympanoplasty. 90 cases were operated under local anaesthesia and 10 cases were operated under general anesthesia. Four types of autogeneus tissues were used as grafting material. Temporalis fascia was used in 36 cases, Tragal perichondrium in 9 cases, Areolar tissue in 9 cases, and Fat from Lobule of same ear in 46 cases. Routine hemogram, X-Ray Mastoids (Law's Lateral oblique view), X-ray paranasal air sinuses (Occipito-mental view) X-Ray Nasopharynx and pure tone audiometry was performed in both air and bone conduction. Both pre and post operative audiometric results were compared to find out the hearing change with these four graft materials. The age of the subjects in this present study ranged from 13 years to 48 years. The maximum numbers of subjects were in age group 21-30 year, followed by 24 subjects in 10-20 years, 34 subjects in 21-30 years, 30 subjects in 31-40 years, 12 subjects in 41-50 years, of age group respectively. Mean age was 28.9 years

\section{Table 1: Age Distribution}

\begin{tabular}{|l|l|}
\hline Age in years & No. of subjects \\
\hline $0-10$ & - \\
\hline $11-20$ & 24 \\
\hline $21-30$ & 34 \\
\hline $31-40$ & 30 \\
\hline $41-50$ & 12 \\
\hline
\end{tabular}

The age of the subject in this present study ranged from 13 years to 48 years. The maximum numbers of subjects were in age group 21-30 year, followed by 30 subjects in 30-40 years, followed by 24 and 12 subjects in 11-20 year and 40-50 years age group respectively. Mean age was 28.9 years.

Table 2: Distribution Of Size And Size Of Central Perforation (Small $<50 \%$ area of Tympanic Membrane)

\begin{tabular}{|l|l|}
\hline Age in years & No. of subjects \\
\hline A. Anterior & $\begin{array}{l}\text { Tiny }<5 \% \text { area }-30 \text { cases Perforation } \\
\text { Moderate }>5 \% \text { area }-8 \text { cases }\end{array}$ \\
\hline B. Posterior & $\begin{array}{l}\text { Tiny }<5 \% \text { area }-14 \text { cases Perforation } \\
\text { Moderate }>5 \% \text { area }-6 \text { cases }\end{array}$ \\
\hline Large & $\begin{array}{l}50 \% \text { area of tympanic membrane Big central } \\
\text { Perforation }=42 \text { cases }\end{array}$ \\
\hline
\end{tabular}

The perforation of various sizes and sites of pars tensa were recorded in study. All of them had central perforation. They were divided into small $<50 \%$ area of tympanic membrane and large $>50 \%$ area of tympanic membrane. Small perforations 58 in number were divided in to Anterior (Tiny $<5 \%$ area -30 cases, Moderate $>5 \%$ to $<50 \% 8$ cases) and posterior (Tiny $<5 \%$ area 14 cases and moderate $>5 \%$ to $<$ $50 \%$ area 6 cases) according to the position in relation to handle of maleus. Large perforations contained only central perforation occupying $>50 \%$ area of tympanic membrane of which 42 cases were seen. mastoids (Law's lateral oblique view) revealed sclerotic pattern in 76 cases and cellular pattern in 24 cases. X-Ray paranasal sinuses (occipitomental view) revealed Hazy (mucosal thickening) in 23 cases while 77 cases were normal. They were treated conservatively with nasal decongestive drops and antibiotics. No. cases, however, showed abnormal X-Ray nasopharynx or gross deformity of septum. None of them required any special tests. Pre operative and post operative audiometric assessment was performed in all 100 subjects both in air and bone conduction. There audiometry values were averaged at 500 $\mathrm{Hz}, 1 \mathrm{KHz}, 2 \mathrm{KHz}, 3 \mathrm{KHz}, 4 \mathrm{KHz}$. Conductive deafness was detected in all cases. Cochlear reserve was found to be within normal limit in all cases. Average air conduction threshold ranged from $22.8 \mathrm{~dB}$ to $47.7 \mathrm{~dB}$ with the mean value of $32.3 \mathrm{~dB}$. The average bone conduction threshold ranged from $6.6 \mathrm{~dB}$ to $13 \mathrm{~dB}$ and the mean value $8.30 \mathrm{~dB}$. The average air bone gap (A-B gap) was noted within range from $16.2 \mathrm{~dB}$ to $41.1 \mathrm{~dB}$ with the mean value $27.6 \mathrm{~dB}$.

In 24 cases of group I (11-20 years) average air - bone gap ranged from $25.0 \mathrm{~dB}$ to $26.6 \mathrm{~dB}$ with mean average $26.2 \mathrm{~dB}$. In group II (21-30 yrs) 34 cases had average air bone gap ranging from $24.6 \mathrm{~dB}$ to $30.0 \mathrm{db}$ with mean of 26.3. In group (III) (31- 40 year) 30 cases and group IV (41 50 years) 12 cases average air bone gap ranged $27.2 \mathrm{~dB}$ to $35.0 \mathrm{~dB}$ and $25.3 \mathrm{~dB}$ to $41 \mathrm{~dB}$ with mean average $28.9 \mathrm{~dB}$ and $35.6 \mathrm{~dB}$ respectively.

Table 3: Audiometric Assessment With Respect To Site Of Perforation

\begin{tabular}{|l|l|l|l|}
\hline & No. of cases & $\begin{array}{l}\text { Average } \\
\text { A-B gap range (dB) }\end{array}$ & $\begin{array}{l}\text { Mean A-B } \\
\text { gap (dB) }\end{array}$ \\
\hline $\begin{array}{l}\text { Anterior } \\
\text { perforation }\end{array}$ & 36 & $18.3-31.2$ & 22.7 \\
\hline $\begin{array}{l}\text { Posterior } \\
\text { perforation }\end{array}$ & 22 & $19.6-32.3$ & 23.3 \\
\hline $\begin{array}{l}\text { Central } \\
\text { perforation }\end{array}$ & 42 & $25.9-41.1$ & 38.3 \\
\hline
\end{tabular}

Out of 100 cases 36 cases were of anterior perforation followed by 22 cases and 42 cases of posterior and central perforation. The average air- bone gap ranges from $18.3(\mathrm{~d} \mathrm{~B})$ to $31.2(\mathrm{~d} \mathrm{~B})$ with mean of 22.7 (d $\mathrm{B}$ ) for anterior perforation. The average air bone gap for posterior and central perforation ranged from 19.6 to $32.3(\mathrm{~d} \mathrm{~B})$ and 25.9 to 41.1 (d B) with mean of 23.3 and 38.3 (d B) respectively. These sites were decided according to their relation to handle of maleus.

Out of 100 cases 58 were of small size perforation that is $<50 \%$ of tympanic membrane area. The average air-bone gap range was 18.9 to 31.8 (d B) with mean of $22.9 \mathrm{~dB}$. Remaining 42 cases were of large perforation occupying $>50 \%$ of tympanic membrane area. The average air- bone gap ranged 25.9 to $41.1(\mathrm{~d} \mathrm{~B})$ with mean of $38.3(\mathrm{~d} B)$. These results were irrespective of graft material used.

Table 4: Graft Materials Used In Type - I Tympanoplasty

\begin{tabular}{|l|l|}
\hline Material used & No. of subjects \\
\hline Temorlis fascia & 36 \\
\hline Tragal perichondrium & 9 \\
\hline Areolar tissue & 9 \\
\hline Fat from ear lobule & 46 \\
\hline
\end{tabular}

In the present study of 100 cases Temporalis fascia was taken in 36 cases followed by Tragal perichondrium with 9 cases followed by areolar tissue with 9 cases and fat from same ear lobule in 46 cases.

On Type -I tympanoplasty successful closure of $22(93 \%)$ out of 24 cases of perforation in age group $11-20$ years with mean improvement of $9.3 \mathrm{~dB}$ followed by successful closure of $32(95 \%)$ out of 34 cases of perforation. In $21-30$ years age group with mean hearing improvement of $9.8 \mathrm{~dB}$ was seen. There was $26(87 \%)$ out of 30 cases who showed successful closure of their perforations in age group $31-40$ years followed by successful closure of $9(77 \%)$ out of 12 cases in age group $41-50$ years with mean hearing improvement of 8.6 and $8.27 \mathrm{~dB}$ respectively.

In $33(93 \%)$ out of 36 cases of anterior perforation successful closure of perforation and mean improvement in hearing of $7.2 \mathrm{~dB}$ was noted, followed by $20(92 \%)$ out of 22 cases of posterior perforation with mean improvement in hearing of $7.5 \mathrm{~dB}$. There was $37(89 \%)$ out of 42 cases of central perforation who showed successful closure and mean improvement of hearing was $9.9 \mathrm{~dB}$. 
closure with mean hearingimprovement of $7.3 \mathrm{~dB}$ and out of 42 cases of largeperforation, $37(89 \%)$ cases showed successful closure of perforation with mean hearing improvement of $9.9 \mathrm{~dB}$.

Out of 76 operated cases of sclerotic mastoid 70(93\%) showed successful closure of perforation. And out of 24 operated cases of cellular mastoid $20(86 \%)$ showed successful closure of perforation.

$34(95 \%)$ out of 36 cases showed successful closure using temporalis fascia with mean hearing improvement of $9.3 \mathrm{~dB}$ followed by $8(90 \%)$ out of 9 cases who showed successful closure using tragal perichondrium with mean hearing improvement of $8.5 \mathrm{~dB}$. Successful closure of $7(80 \%)$ cases out of 9 cases using Areolar tissue was noticed with $8.9 \mathrm{~dB}$ mean hearing improvement followed by success of 41 $(90 \%)$ out of 46 cases using fat from ear lobule with mean hearing improvement of $6.8 \mathrm{~dB}$.

Table 5: Overall Successful Closure In Type - I Tympanoplasty

\begin{tabular}{|l|l|}
\hline Operated ear & Successful closure of perforation \\
\hline 100 & $90(90 \%)$ \\
\hline
\end{tabular}

\section{DISCUSSION}

Type - I Tympanoplasty operations were performed by Four graft materials (i) temporalis fascia in 36 cases (ii) tragal perichondrium in 9 cases and (iii) ) Arcolar tissue 9 cases (IV) Ear lobule fat 46 cases and followed up for 3-6 month. Postoperative pure tone audiometry was performed using the same frequencies as pre-operatively and the air bone gap $(\mathrm{dB})$ and the average threshold of hearing was recorded. These tests were performed only on successful closure cases after 12 weeks follow up period (Mendel ET AL 1980). The audiometric values were then compared with preoperative values. Various authorities used different criteria for assessing the results of myringoplasty like Proctor (1960) advocated a social hearing method; Portman (1963) favoured a hearing gain method. Elbroud (1970) used the mean air bone gap for each frequency. Booth (1972) expressed that subjective improvement of the patient and the air conduction gain was superior to the air bone gap. He mentioned that sometimes there was improvement in bone conduction also after myringoplasty. The successful heaving improvement in this study was considered according to criteria proposed by kurtush in Glasscock $5^{\text {th }}$ edition as explained earlier. If post operative air bone gap was $11-20 \mathrm{~dB}$ or below, that is in the good range according to this criteria then we considered our tympanoplasty as successful.

In the present study maximum successful closure of perforation $95 \%$ (33 cases) with maximum successful hearing improvement of 84\% (29 cases) was in 21-30 yrs age group. In 11-20 yrs age group successful closure was of $93 \%$ perforations with successful hearing in $68 \%$ followed by 31-40 yrs age group with successful closure of $87 \%$ perforations and successful hearing in $74 \%$. The least successful was $41-50$ yrs age group with successful closure of $77 \%$ perforations and successful hearing in just $60 \%$. StorahanET AL (1971) mentioned that graft failure and poor hearing were observed more common in older age group ( $85 \%$ success in $21-30$ yrs and $58 \%$ success in $31-40 \mathrm{yrs}$ ) where as successful closure and hearing improvement were universally good in youngest age group. In the present study of 100 cases using four autogenous graft materials successful closure was seen in $90 \%$ cases with successful hearing of $74 \%$ cases. Hough (1970) in his study achieved hearing improvement any average $81.1 \%$ ay cases

\section{CONCLUSION}

Tympanoplasty using Fat from ear lobule has high success rate of $90 \%$ for tiny small perforations. It is an office procedure which is cost effective with minimum post operative morbidity. But it is an underused procedure. We should practice it more for the benefit of our patients. Further long term study with more number of patients and verities of graft materials are necessary to achieve detailed and accurate results.

\section{REFERENCES}

1. Abdelhameed W, Rezk I, Awad A. Impact of cartilage graft size on success of tympanoplasty. Braz J Otorhinolaryngol.2016. http://dx.doi.org/10.1016/j.bjorl.2016. 06.005

2. AbouMayeleh h, Heshiki R, Postmann D, Negrevergne M (2005) Reinforcing tympanoplasty the cartilage mosaic (differences from the palisade technique ). Rev LaryngolOtolRhinol(Bord) 126(3): 181-9.

3. Batni G, Goyal R. Hearing outcome after type 1 tympanoplasty: A reterospective study. Indian J Otolaryngol Head Neck Surg. 2015;67(1):39-42.

4. Chandrashekar Y et al. Comparison of efficacy of myringoplasty in dry and wet ears in chronicotitis media of tubotympanic type.Int J Otorhinolaryngol Head Neck Surg. 2017
Jul;3(3):705-709.

5. Chhapola S, Matta I. Cartilageperichondrium: An ideal graft material? Indian J Otolaryngol Head Neck Surg. 2012;64(3):20813.

6. Deenadayal DS, Neeli AK, Patel SH. Graft uptake rates with isoamyl2 cyanoacrylate in myringoplasty procedures: A 10 year retrospective study. Otolaryngol Head Neck Surg. 2011;145(3):44245

7. Gamra OB, Mbarek C, Khammassi K, Methlouthi N, Ouni H; Cartilage graft in type tympanoplasty: audiological and otological outcome: Eur Arch Otorhinolaryngol. 2008 Jul; 265(7):739-42. Epub 2008 Mar 20

8. Halim A, Borgstein J: Pediatric myringoplasty: postaural versus transmeatal approach Int J PediatrOtorhinolaryngol. 2009 Nov;73(11):1580-3

9. Hardman J1, Muzaffar J, Nankivell P, Coulson C: Tympanoplasty for Chronic Tympanic Membrane Perforation in Children: Systematic Review and Meta-analysis. OtolNeurotol. 2015 Jun:36(5):796-804.

10. Hosamani, P., Ananth, L., \&Medikeri, S. (2012). Comparative study of efficacy of graf placement with and without anterior tagging in type one tympanoplasty for mucosaltype chronic otitis media. The Journal of Laryngology\& Otology, 126(2), 125-130. doi:10.1017/S0022215111002659. House , W.F. (1960) Myringoplasty “ Archives of Otolaryngology, 71:399-404

11. Jiang H, Zhang Z (2014) Cartilage Tends To Be a Better Choice than Temporalis Fascia for Tympanoplasty under the Circumstance of EustachianTube Dysfunction. Ann OtolaryngolRhinol 1(3): 1013 .

12. Kishore Chandra Prasad et all (2009): Assessment of eustachian tube function in tympanoplasty. Otolaryngology-Head and Neck Surgery (2009) 140,889-893.

13. Kulduk E, Dundar R, Soy FK, Guler OK, Yukkaldiran A, Iynen I, et al. Treatment of large tympanic membrane perforations: Medial to malleus versus lateral to malleus. Indian J Otolaryngol Head Neck Surg. 2015;67(2):173-79.

14. Manu Malhotra, SaurabhVarshney, RashmiMalhotra (2017): Indian Perspectives on Graft Materials Used for Repair of Tympanic Membrane. Journal of Clinical and Diagnostic Research. 2017 Jul, Vol-11(7): ME01-ME06.

15. Mills R, Thiel G, Mills N. Results of myringoplasty operations in active and inactive ears in adults. Laryngoscope. 2013;123(9):2245-9.

16. Rakesh Kumar, et at: Comparative Study of Underlay Tympanoplasty with Temporalis Fascia and Tragal Perichondrium. IOSR Journal of Dental and Medical Sciences (IOSRJDMS). Volume 13, Issue 5 Ver. III. (May. 2014), PP 89-98.

17. Shwan H. Mohamad, Imran Khan, and S. S. MusheerHussain (2012): Is Cartilage Tympanoplasty More Effective Than Fascia Tympanoplasty? A Systematic Review. Otology \&Neurotology, Vol. 33, No. 5, 2012

18. Yetiser S, Hidin Y. Temporalis fascia and cartilage perichondrium composite shield graf for reconstruction for tympanic membrane. The Annals of Otology, Rhinology and Laryngology. 2009; 118(8):570-4

19. Yu MS, Yoon TH (2010) Bilateral same-day surgery for bilateral perforated chronic otitis media: inlay butterfly cartilage myringoplasty. Otolaryngol Head Neck Surg 143:669-672 